\title{
RANCANG BAGUN SISTEM INFORMASI AGENDA KERJA UNTUK ANGGOTA KEPOLISIAN BERBASIS KINERJA MENGGUNAKAN METODE BERORIENTASI OBJEK
}

Edy Siswanto ${ }^{1}$, Sugiarto Sugiarto ${ }^{2}$

1,2Universitas Sains dan Teknologi Komputer

Jalan majapahit No605 Semarang, edysiswanto@stekom.ac.id; sugiarto@stekom.ac.id

\section{ARTICLE INFO}

Article history:

Received 30 Agustus 2021

Received in revised form 2 September 2021

Accepted 10 September 2021

Available online 1 Desember 2021

\section{ABSTRACT}

Within the body of the National Police, the Polsekta / Polsek have an important role in protecting, nurturing, serving and enforcing the law in the Tegowanu Police area community. Therefore, the Tegowanu Police are required to be able to serve the community where one of the main tasks of the Republic of Indonesia Police is as a public servant. As one of the law enforcement officers, the National

The old work agenda system still uses manual methods and takes a lot of time and with this system will slow down the performance of Polsek members. Documentation of activities carried out by the Tegowanu Police Officer cannot be seen by the police chief and members, because photo documentation is only stored on the officer's computer. Another problem is that there is no data storage for community activity data and activity schedules, because there is no storage in the database so that data processing has not been well integrated.

By designing a Performance-based Activity information system using the Object Oriented Method at the Tegowanu Police, Resort Grobogan is expected to help data processing so that it is more well integrated and the reporting process and data retrieval are faster if data is needed at any time and create an integrated system with the database. The information that will be built can speed up the process of processing and sending information and activities of the Tegowanu Police to the head of the Sector Police.

Keywords: System, Agenda, Work, Performance, Oriented

\section{Pendahuluan}

Teknologi pada masa sekarang ini, sudah sangat cepat dan maju, salah satunya adalah teknologi komputer. Komputer pada masa sekarang ini sudah bukan barang yang asing dan mahal lagi, pada saat ini hampir disegala bidang membutuhkan komputer sebagai alat bantu, karena memiliki kelebihan yaitu dari

Received Agustus 23, 2021; Revised September 29, 2021; Accepted November 12, 2021 
segi kecepatan dan ketelitian. Misalnya saja dibidang kesehatan, bidang teknik, sipil, perbankan, ilmu pengetahuan, bisnis baik oleh pemerintah maupun swasta. Dimana sekarang juga berkembang teknologi jaringan komputer, dimana orang bisa berkomunikasi dengan menggunakan komputer, yang tidak hanya dalam satu ruangan, tetapi bisa meliputi antar benua, yaitu Internet. Jadi bisa dikatakan komputer telah memasuki segala bidang kehidupan kita.

Pada era globalisasi, aktivitas kehidupan manusia seakan tidak mengenal batas ruang dan waktu dimana dengan didukung derasnya arus informasi dan pesatnya perkembangan ilmu pengetahuan serta teknologi, kulitas dan kuantitas kejahatan semakin meningkat dengan modus operandi serta bervariasi dan canggih serta sulit pembuktiannya mulai dengan kejahatan bersifat konvensional, kejahatan terorganisir, kejahatan kerah putih sampai pada kejahatan yang aktivitasnya lintas negara. Situasi dan kondisi ini, merupakan tantangan tersendiri bagi Instansi Polri khususnya Polsek Tegowanu Plores Grobogan sebagai institusi yang dipercaya masyarakat dalam melindungi, mengayomi dan melayani masyarakat.

Dalam tubuh Polri yaitu Polsekta / Polsek memiliki peranan penting dalam melindungi, mengayomi, melayani dan penegakkan hukum dimasyarakat wilayah Polsek Tegowanu. Karena itu Polsek Tegowanu dituntut mampu melayani masyarakat dimana salah satu tugas utama dari Polisi Republik Indonesia adalah sebagai pelayan masyarakat. Sebagai salah satu aparatur penegak hukum, Polri banyak menjadi sorotan masyarakat terkait penyimpangan dalam menegakkan hukum, sebagai akibat kurangnya pemahaman tentang peraturan perundang-undangan sebagai instrumen hukum, sehingga diperlukan suatu sistem untuk internal Polri yang memberikan informasi agenda kerja, sehingga setiap anggota Polri bertindak sesuai ketentuan hukum yang ada.

Sistem agenda kerja yang sekarang ada di Polsek masih menggunakan cara manual dan memakan banyak waktu dengan sistem ini akan menperlambat kinerja para anggota Polsek. Dokumentasi kegiatan yang di laksanakan oleh Petugas Polsek Tegowanu tidak dapat dilihat oleh kapolsek dan anggota, karena dokumentasi foto hanya tersimpan di komputer petugas. Permasalahan yang lainnyaPolsek Tegowanu belum mempunyai data penyimpanan data kegiatan kemasyrakatan dan jadwal kegiatan, karena tidak ada penyimpanan di database sehingga pengolahan data belum terintegrasi dengan baik. Hal tersebut mendorong peneliti untuk mencoba membuat sendiri sistem informasi agenda kerja.

Dengan merancang sistem informasi Kegiatan berbasis Kinerja pada Polsek Tegowanu menggunakan metode Berorientasi Objek, Resort Grobogan diharapkan dapat membantu pengolahan data supaya lebih terintregasi dengan baik serta proses laporan dan pencarian data lebih cepat jika sewaktuwaktu data dibutuhkan dan membuat sistem yang terintegrasi dengan database. Informasi yang akan dibangun dapat mempercepat proses pengolahan dan pengiriman informasi serta kegiatan Polsek Tegowanu ke Kapolsek

\section{Metode Penelitian}

Untuk mengembangkan suatu Sistem Informasi Agenda Kerja Polsek Tegowanu Kabupaten Grobogan Berbasis kinerja untuk membantu memecahkan permasalahan yang ada, diperlukan persiapan dan perencanaan yang teliti. Dalam pengembangan ini akan dikemukakan model pengembangan sebagai dasar pengembangan produk. Model yang akan dikembangkan adalah mengacu pada model Research and Development (R\&D). [9]

Mengacu pada model pengembangan Sugiyono ada langkah pelaksanaan strategi penelitian dan pengembangan yang dilakukan untuk menghasilkan produk tertentu untuk menguji keefektifan produk yang dimaksud. Adapun langkah-langkah penelitian dan pengembangan yang peneliti lakukan dengan menyerdehanakan menjadi enam tahapan sebagai berikut: (1) Potensi dan masalah, (2) Pengumpulan data, (3) Desain produk, (4) Validasi desain, (5) Revisi desain, (6) Ujicoba produk. Adapun bagan langkahlangkah penelitiannya seperti ditunjukkan pada gambar berikut.

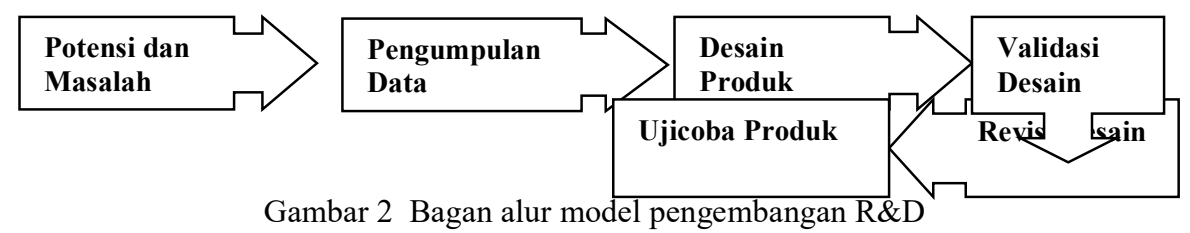

Rancangan pengembangan dengan desain R \& D mempunyai tujuan untuk mengembangkan dan memvalidasi produk. Pengembangan produk yang dilaksanakan pada penelitian ini hanya sampai pada tahap menghasilkan produk akhir, yaitu mengenali potensi masalah sampai prothotype produk sehingga

JURNAL ILMIAH ELEKTRONIKA DAN KOMPUTER Vol. 14, No. 2, Desember 2021: 181 - 189 
dapat dilakukan penelitian lanjutan. Dalam tahap metode pengembangan yang akan dilaksanakan menggunakan model pengembangan Research and Development (R\&D), dimana ada 6 langkah yang akan dipakai dalam penelitian. Pada tahap pertama yang perlu dilaksanakan dalam pengembangan ini dimulai menganalisa suatu masalah yang sedang dihadapi. Tahap ini dimulai dengan mengidentifikasi masalah yang ada dan menggali potensi yang ada di tempat penelitian yang akan akan diteliti. Pada tahap selanjutnya pengumpulan data dengan cara pengamatan, wawancara serat observasi secara langsung, data yang didapat meliputi data Anggota, Kegiatan Agenda Kerja.

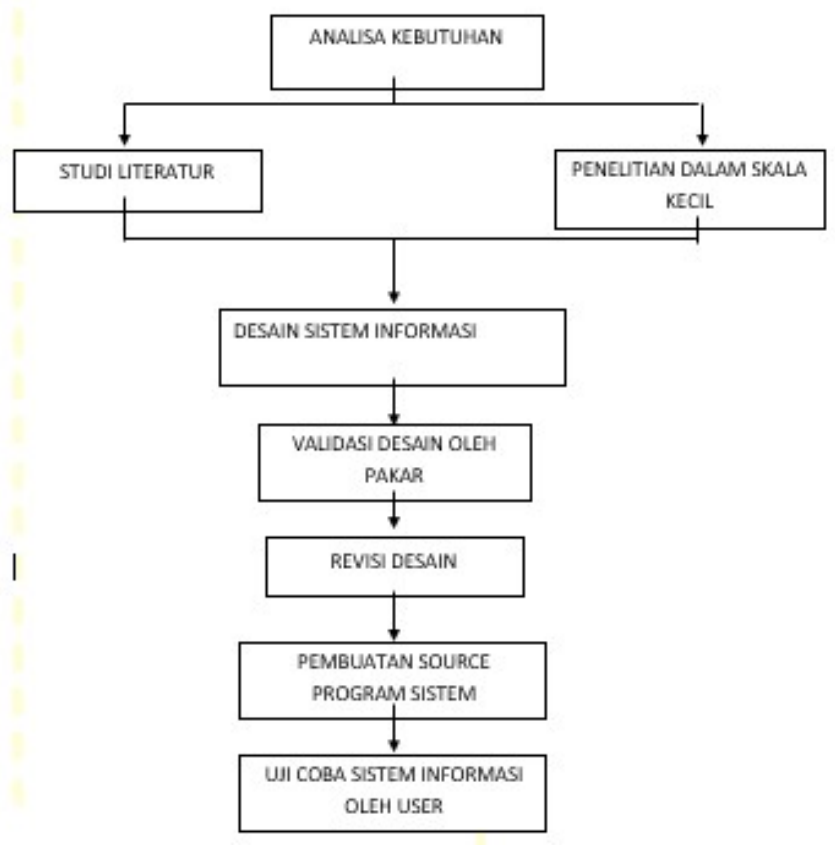

GAMBAR 3. PROSEDUR PENGEMBANGAN

Setelah tahap pengumpulan data sudah didapatkan, tahap selanjutnya melakukan tahap pengembangan. Pada tahap pengembangan ini, produk yang akan dibuat dianalaisa kemudian direncanakan serta mendesign produk yang akan dibuat. Tahap selanjutnya produk yang akan dikembangkan kemudian diajukan ke pembimbing kemudian jika ada revisi kemudian diperbaiki. Tahap terakhir sebelum digunakan produk perlu diuji validasi dahulu. Pada tahap uji validasi dilakukan oleh pakar internal maupun exsternal yang berkompeten dalam menjalankan suatu program yang sudah dibuat. Setelah produk selesai tahap selanjutnya produk siap digunakan

\section{Analisa Sistem}

Penelitian ini dilakukan pengujian validasi oleh pakar dan validasi produk oleh user atau pengguna, validasi desain yang dilakukan oleh pakar dan validasi produk oleh user menggunakan instrument penilaian angket yang berupa lembar validator. Penilaian tersebut digunakan sebagai indicator dan kesimpulan dalam memberikan nilai terhadap hasil validasi. Berikut keterangan kesimpulan hasil penelitian dan indikator nilai yang dilakukan :

Tabel 1 Nilai Indikator

\begin{tabular}{|c|c|}
\hline SKOR & NILAI \\
\hline $1 \leq n \leq 10$ & Tidak baik \\
\hline $11 \leq n \leq 20$ & Cukup \\
\hline
\end{tabular}

RANCANG BAGUN SISTEM INFORMASI AGENDA KERJA UNTUK ANGGOTA KEPOLISIAN BERBASIS KINERJA MENGGUNAKAN METODE BERORIENTASI OBJEK 


\begin{tabular}{|c|c|}
$21 \leq n \leq 30$ & Baik \\
\hline $31 \leq n \leq 40$ & Sangat baik \\
\hline
\end{tabular}

Tabel 2 Kesimpulan

\begin{tabular}{|c|l|}
\hline NO & \multicolumn{1}{|c|}{ SIMPULAN } \\
\hline 1 & Belum dapat digunakan dan harus diganti \\
\hline 2 & Dapat digunakan dengan banyak revisi \\
\hline 3 & Dapat digunakan dengan sedikit revisi \\
\hline 4 & Dapat digunakan tanpa revisi \\
\hline
\end{tabular}

Perancangan Sistem Informasi Agenda Kerja Berbasis Kinerja pada Polsek Tegowanu Polres Grobogan telah di validasi oleh pakar yang di wakili oleh dosen STEKOM yang kompeten dalam bidangnya. Pakar yang memvalidasi rancangan ini ditunjuk oleh STEKOM dan merupakan dosen dari STEKOM sendiri.

Hasil dari penelitian berupa angket oleh subjek penelitian dapat dilihat pada lampiran. Tabel rekap angket dapat dilihat pada tabel 3 dibawah ini:

\begin{tabular}{|c|c|}
\hline Indikator No & Nilai Indikator \\
\hline 1 & 3 \\
\hline 2 & 3 \\
\hline 3 & 4 \\
\hline 4 & 3 \\
\hline 5 & 3 \\
\hline 6 & 3 \\
\hline 7 & 3 \\
\hline 8 & 3 \\
\hline 9 & 30 \\
\hline 10 & \\
\hline Total Akhir & \\
\hline
\end{tabular}

Tabel 3 Tabel Rekap hasil angket validasi desain oleh pakar

Hasil pengujian validasi desain oleh pakar memberikan skor nilai 30 yang didapat untuk rancangan desain aplikasi ini masuk dalam indikator skor $21 \leq n \leq 30$ adalah "Baik". Kesimpulan yang diambil oleh pakar untuk rancangan system ini adalah "Baik, Sehungga dapat digunakan dengan sedikit revisi.

\section{Uji lapangan}

Pengujian validasi desain produk oleh user / pengguna dilakukan oleh admin, Kapolsek, Petugas Polisi. Berikut hasil validasi produk oleh user / pengguna :

JURNAL ILMIAH ELEKTRONIKA DAN KOMPUTER Vol. 14, No. 2, Desember 2021: 181 - 189 
Tabel 4 Rekap hasil angket

\begin{tabular}{|l|l|l|l|l|}
\hline $\begin{array}{l}\text { Indikator } \\
\text { No }\end{array}$ & User 1 & User 2 & User 3 & $\begin{array}{l}\text { Rata-Rata Tiap } \\
\text { Indikator }\end{array}$ \\
\hline 1 & 4 & 4 & 3 & 3,6 \\
\hline 2 & 3 & 3 & 3 & 3,4 \\
\hline 3 & 4 & 4 & 3 & 3,6 \\
\hline 4 & 3 & 3 & 3 & 3,2 \\
\hline 5 & 3 & 3 & 3 & 3,2 \\
\hline 6 & 4 & 3 & 3 & 3,2 \\
\hline 7 & 4 & 3 & 3 & 3,4 \\
\hline 8 & 4 & 3 & 3 & 3,4 \\
\hline 9 & 4 & 4 & 3 & 3,8 \\
\hline 10 & 4 & 3 & 3 & 3,4 \\
\hline Total Akhir & 37 & 33 & 30 & 34,2 \\
\hline Rata-Rata hasil pengujian oleh 3 user & $\mathbf{3 4 , 2}$ \\
\hline
\end{tabular}

Hasil skor rata-rata yang didapat pada validasi produk oleh user yaitu 34,2 poin. Keterangan :

User $1: 37$ Poin

User $2: 33$ Poin

User $3: 30$ Poin

Hasil pengujian validasi desain produk oleh user / pengguna memberikan skor nilai 34,2.

Nilai ini didapat dari penjumlahan total skor yang diberikan ketiga user kemudian dibagi tiga sehingga menghasilkan nilai 34,2 poin. Masuk dalam kategori indicator $21 \leq n \leq 30$ Baik, sehingga dapat disimpulkan produk prototype "dapat digunakan dengan sedikit revisi”.

\section{Hasil dan Pembahasan}

Hasil Desain Input dan Output merancang Sistem Informasi Agenda Kerja Berbasis Kinerja pada Polsek Tegowanu Polres Grobogan dan Dokumentasi kegiatan dan jadwal agenda yang dilaksanakan oleh petugas Polsek Tegowanu dapat dilah sebagai berikut:

a) Desain Halaman Utama

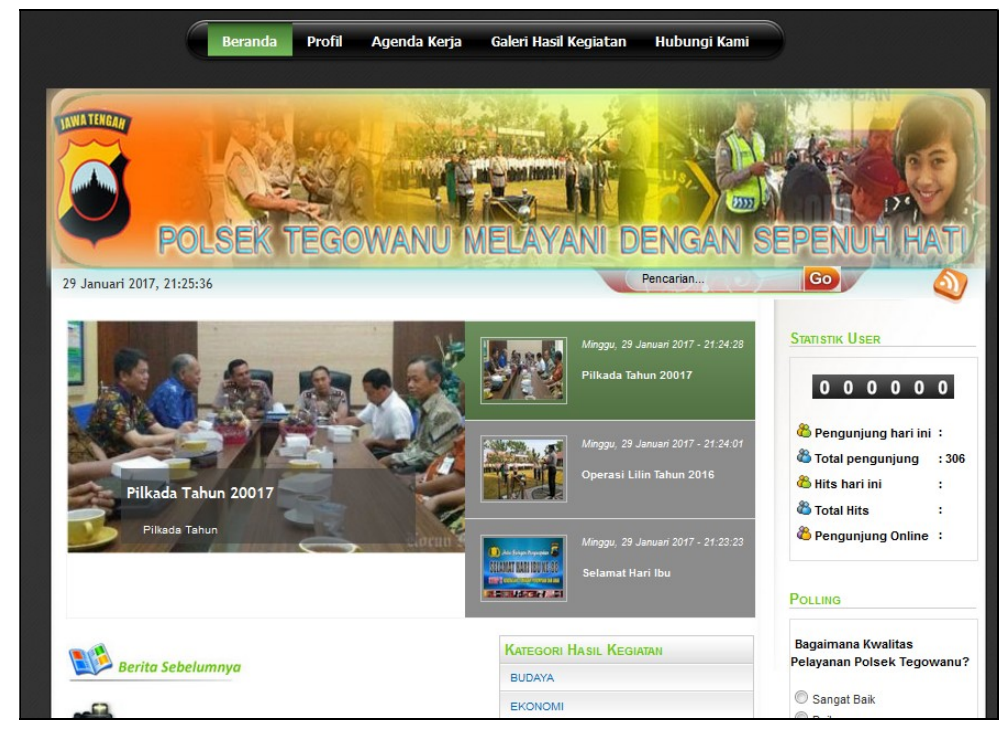

Gambar 1 Halaman Utama 
Halaman utama Sistem Informasi Agenda Kerja Berbasis Kinerja pada Polsek Tegowanu Polres Grobogan, merupakan salah satu alat untuk mengenalkan kegiatan Polsek Tegowanu Polres Grobogan. Semua menu akan ditampilkan pada halaman ini, sehingga pengunjuk dapat dengan mudah mengakses seluruh menu yang ada.

b) Halaman Hubungi Kami

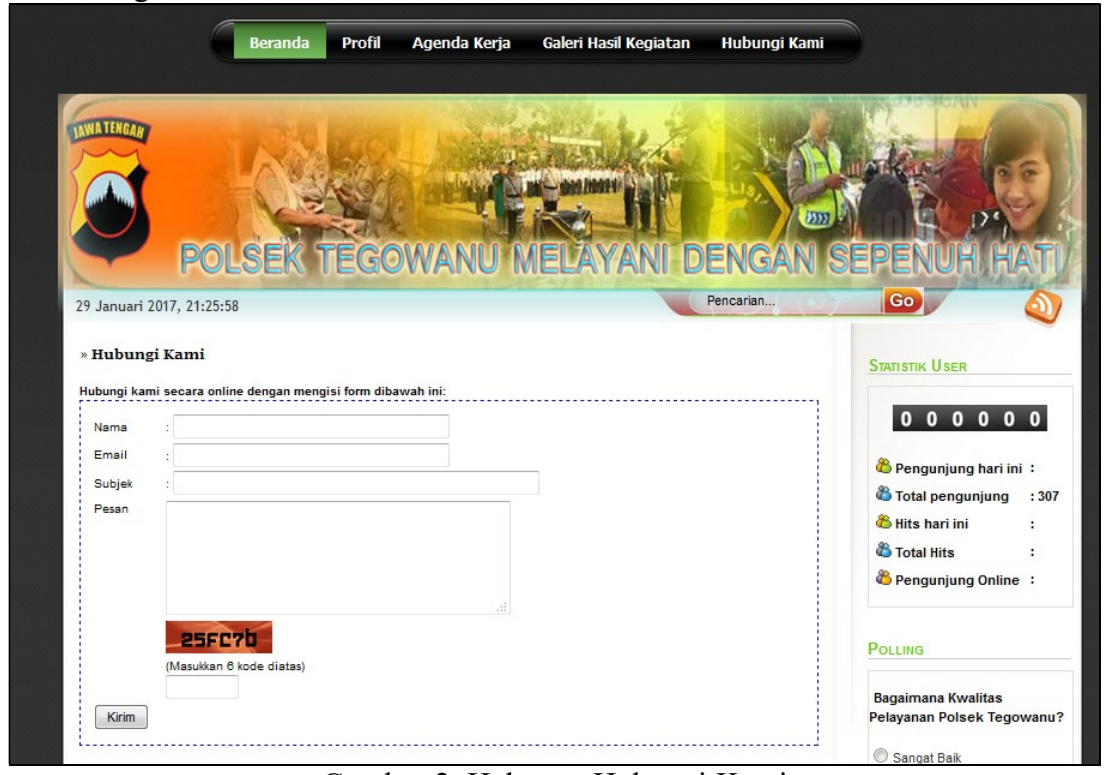

Gambar 2 Halaman Hubungi Kami

Dengan mengklik link buat Hubungi Kami maka Masyrarakat Kecamatan Tegowanu dapat menghubungi Petugas Polsek Tegowanu melalui pesan singkat dan memberikan saran dan kritik.

c) Halaman Visi Misi

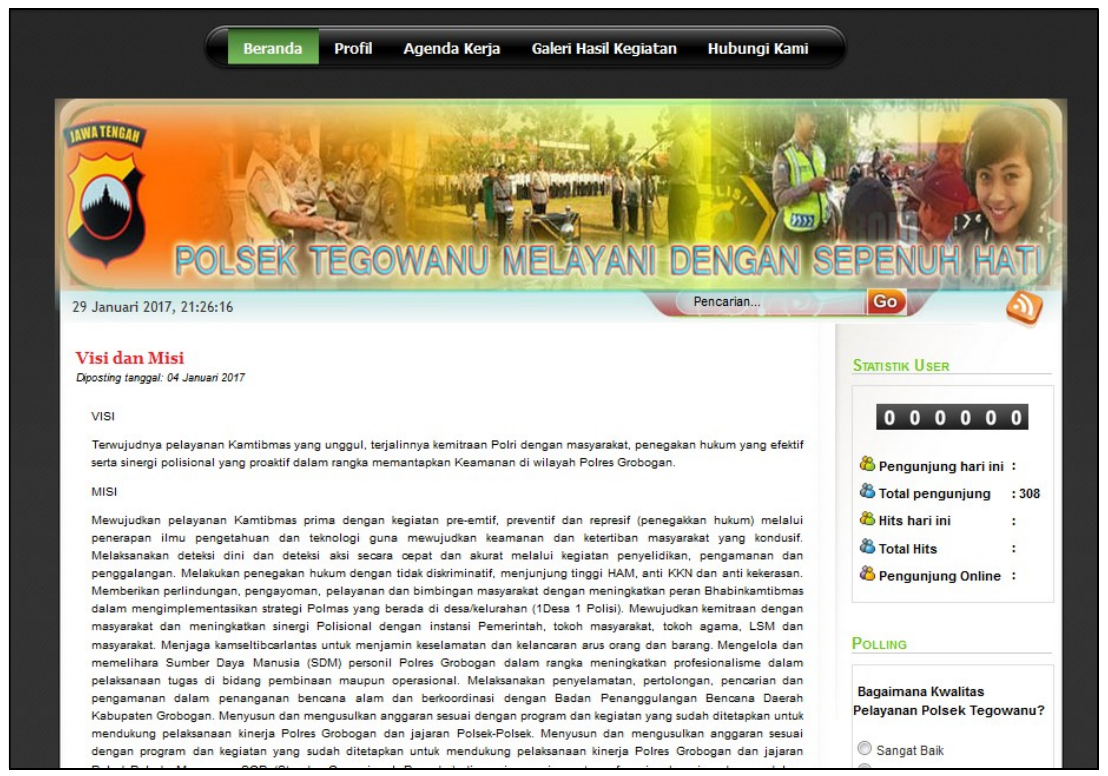

Gambar 3 Visi Misi

JURNAL ILMIAH ELEKTRONIKA DAN KOMPUTER Vol. 14, No. 2, Desember 2021: 181 - 189 
Halaman Visi Misi, memberi gambaran tentang Visi misi Petugas Polsek Tegowanu untuk mengenal akan kegiatan dan jadwal Agenda Kerja Polsek Tegowanu. Untuk melihatnya dapat mengklik menu profile yang ada di sebelah kiri maupun di sebelah atas.

d) Halaman Stuktur Organisai

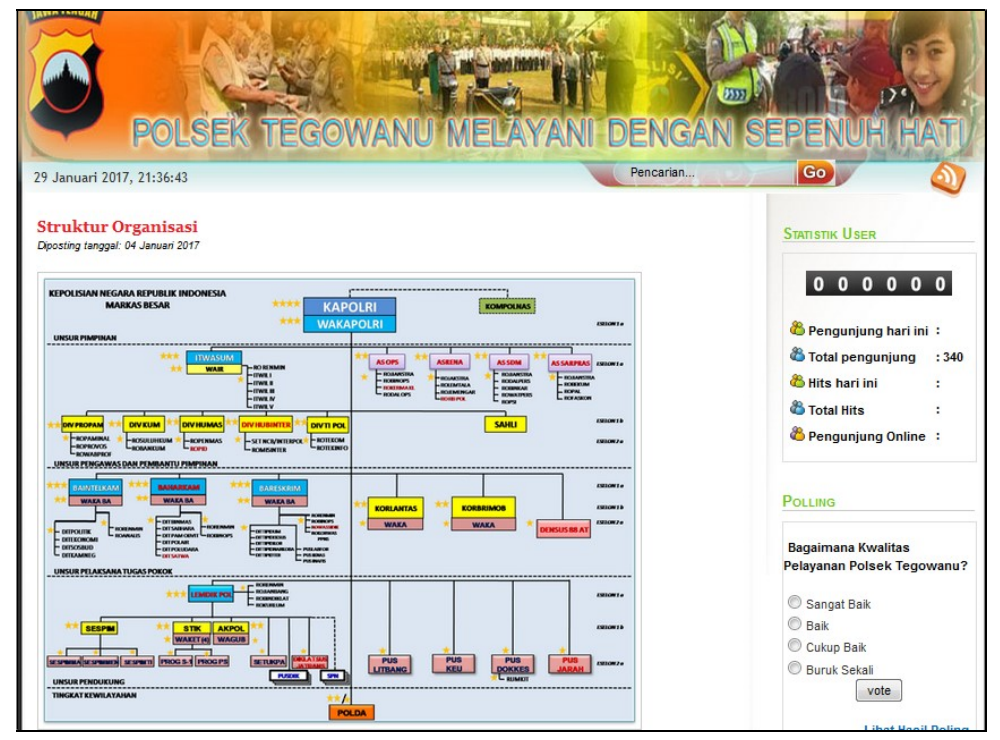

Gambar 4 Halaman Stuktur Organisai

Untuk mengaksesnya Masyrarakat Kecamatan Tegowanu dapat, menglik menu Stuktur Organisai Pada halaman struktur organisasi ini member kan gambaran struktur Petugas Polsek Tegowanu baik dari Petugas Lapangan maupun seksi-seksi dalam Petugas Polsek Tegowanu.

e) Halaman login admin

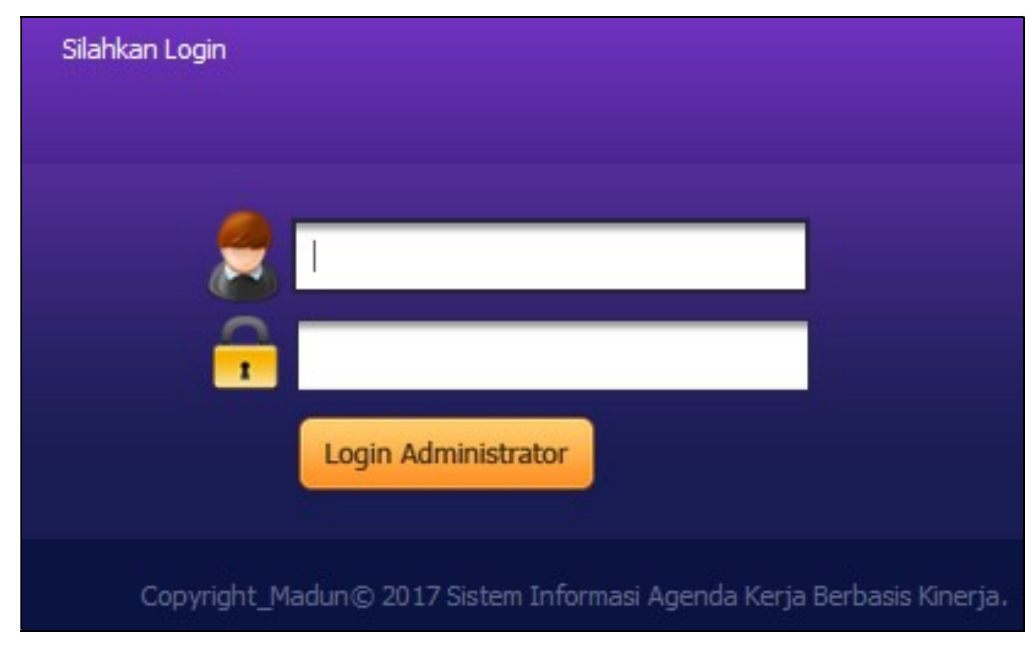

Gambar 5 Halaman login admin

Halaman ini untuk mengakses halam admin. Dimana admin dapat mengubah data yang ada. Untuk mengasesknya dapat melalui alamat local http://localhost/polsek-Tegowanu/adminweb

RANCANG BAGUN SISTEM INFORMASI AGENDA KERJA UNTUK ANGGOTA KEPOLISIAN BERBASIS KINERJA MENGGUNAKAN METODE BERORIENTASI OBJEK 
f) Halaman utama admin

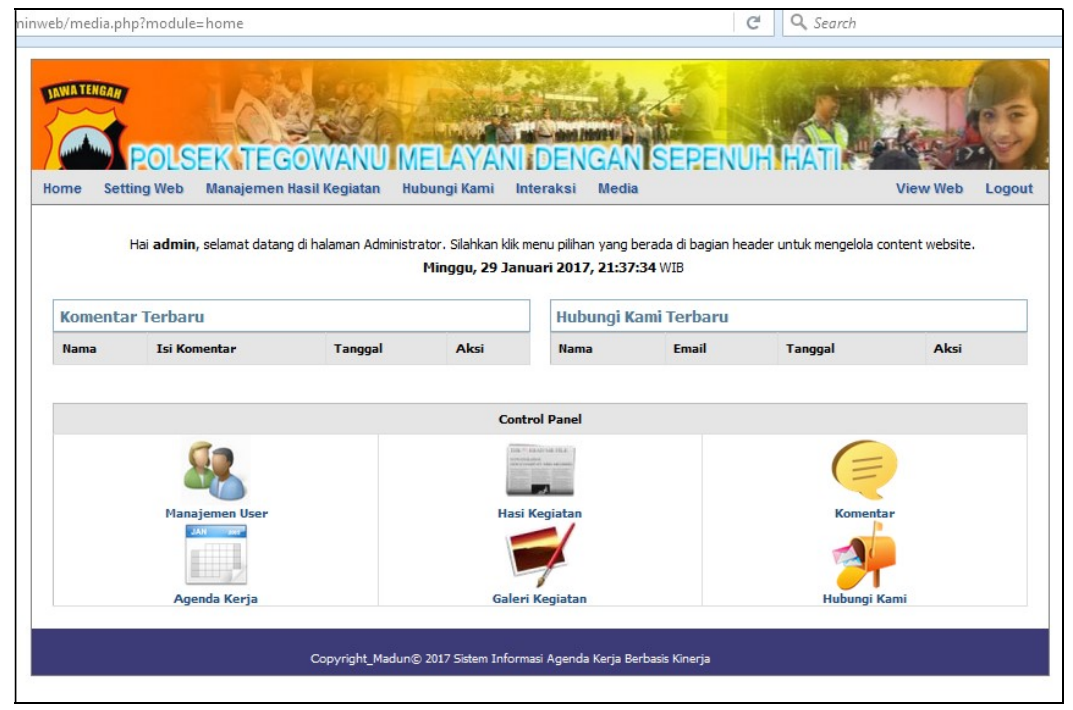

Gambar 6 Halaman utama admin

Halaman utama admin merupakan letak dimana menu-menu untuk menajemen web dan isinya secara keseluruhan. Untuk mengaksesnya hanya user yang didaftarkan yang bisa masuk.

g) Halaman Tambah Data User

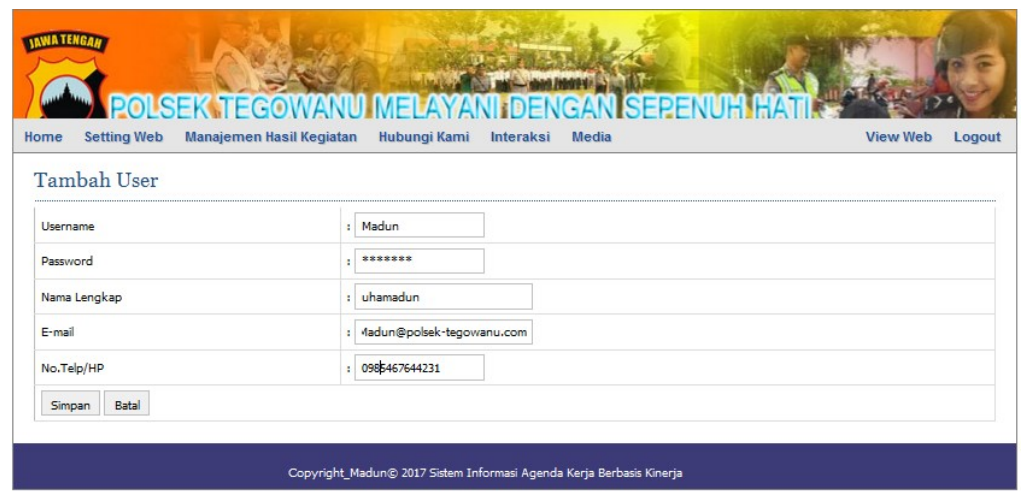

Gambar 7 Halaman Tambah data User

Halaman ini untuk memasukkan data user dengan mengisi form dan mengklik tombol simpan. User yang diinput dapat login kemenu administrator hanya bias membuka dan menginput data agenda dan Petugas Polsek Tegowanu.

\section{Daftar Pustaka}

[1] M.Ichsan Anugra, Joko Susilo, 2012, Sistem Informasi Manajemen Dokumen dan Layanan Masyarakat, Metodologi Fast, PIECES, Polsek Makarti Jaya. Proseding, AMIKOM Tahun 2012

[2] Monica Ws,( 2011), SISTEM INFORMASI AGENDA KERJA POLSEK NGLUWAR MAGELANG. Jurnal Telematika, ISSN 129, 2011

[3] Kusrini, 2011; "Strategi Perancangan dan Pengolahan Basis Data", Yoyakarta : Andi Offse,.

[4] Sutabri, Tata, 2013; "Analisis Sistem Informasi", Jakarta : Percetakan Andi.

JURNAL ILMIAH ELEKTRONIKA DAN KOMPUTER Vol. 14, No. 2, Desember 2021 : 181 - 189 
[5] Husein Umar, 2009, Metode Penelitian untuk Skripsi Dan Tesis Bisnis, Edisikedua, Rajagrafindo Persada Jakarta

[6] Hani Handoko, 2010, Manajemen Personalia \& Sumberdaya Manusia, Edisi kedua, BPFE UGM Yogyakarta

[7] Perkap nomor 23 tahun 2010, tentang Susunan organisasi dan tata kerja pada tingkat kepolisian Resot dan Kepolisian Sektor

[8] Sudirman, Eko Retnadi, Rina Kurniawati, 2012, "Perancangan Program Aplikasi Transaksi Pembayaran SPP, UTS dan UAS Menggunakan Metode Analisis dan Desain Berorientasi Objek Model Unified Approach (UA)”.' ISSN: 2302-7339 Vol. 09 No 182012.

[9] Sugiyono. (2011). Metode Penelitian Kuantitatif Kualitatif dan R\&D. Bandung. Alfabeta 